811.163.41'366

811.163.41'373.611

811.163.41:929 Стакић М.

https://doi.org/10.18485/sj.2020.25.1.2

СНЕЖАНА П. ВУЧКОВИТ

Универзитет у Београду

Филолошки факултет
Оригинални научни рад

Примљен: 15. 10. 2019.

Прихваћен: 15. 01. 2020.

\title{
МОРФОНОЛОГИЈА У НАУЧНИМ РАДОВИМА ПРОФЕСОРА МИЛАНА СТАКИЋА
}

У раду се анализирају теоријски ставови и методолошки приступи које је професор Милан Стакић презентовао у својим чланцима и студијама из области морфонологије. Разматрају се кључна питања и проблеми којима се у овим радовима бавио: однос гласовних промена и гласовних алтернација, дијахронијски и синхронијски аспекти тумачења гласовних закона, природа и функција аналошки мотивисаних алтернација, питање тзв. изузетака, анализа и критика теоријских и методолошких поставки у оквиру којих се ова питања представљају у уџбеницима и приручницима намењеним настави српског језика.

Кључне речи: морфонологија, гласовне промене, гласовне алтернације, аналогија, изузеци, Милан Стакић, теорија, методологија.

1. Професор Милан Стакић се у свом дугом научном раду бавио различитим темама, међу којима значајно место заузима и област морфонологије, којој је посветио посебну пажњу и о којој је опширно и документовано писао у бројним радовима, а посебно у књигама Деривациона фонетика именица и придева ујужнословенским језищима (Београд, Филолошки факултет, Монографије, LXIV, 1988, стр. 1-244) ${ }^{1}$, Морфонологија и деривација (чланци и расправе) (Београд, Филолошки факултет, Научно друштво за неговање и проучавање

*snezanabaukvuckovic@gmail.com

${ }^{1}$ Књига представља скраћену верзију професорове докторске дисертације одбрањене на Филолошком факултету у Београду маја 1986. године. 
српског језика, 2002, стр. 1-317) и Морфо(но)лошке теме (Београд, Друштво за српски језик и књижевност Србије, Београд, 2010, стр. 1-201)2. Преокупација овом граматичком облашћу чини се да није била случајна, будући да је професор Стакић, по свом професионалном опредељењу дијахроничар, један од ретких наших лингвиста који су о језичким појавама и процесима савременог језика говорили и са дијахронијских позиција. У својим анализама професор се није задовољавао само синхронијским описом појединих нивоа језичког система већ је трагао и за историјским узроцима, путевима и начинима њиховог развитка и формирања. Треба нагласити да је професор Стакић притом јасно подвајао дијахронијски од синхронијског приступа проучавању језика и да је укључивање дијахронијских увида, у овим радовима, само доприносило пуноћи и вредности његових анализа и њиховој вишедимензионалности. А управо је морфонологија једна од таквих лингвистичких области у којој се овакав приступ показао као веома плодотворан и подстицајан.

2. Студије и чланци професора Стакића из области морфонологије укључивали су и уже и шире схваћене објекте ове лингвистичке дисциплине. Они се не тичу само појаве алтернирања фонема и њихових типова ${ }^{3}$ - односа фонетских алтернанти (у ужем смислу) и фонетских варијаната, двочланих и трочланих алтернантских реализација, фонолошки и аналошки условљених алтернација (упор. нпр. Типови консонантских алтернација у српскохрватском језику, Научни састанак слависта у Вукове дане, 20/2, Београд, 1990, 403-410; Вокалске алтернације у српском језику, Научни састанак слависта у Вукове дане, 33/3, Београд, 2004, 41-46. и др.), те са овим повезаним разматрањем гласовне структуре морфема различитих видова, њихових разлика (коренске морфеме, облички наставци, творбене морфеме) и односа основе и суфикса у погледу алтернација ${ }^{4}$ - већ се укрштају и са питањем морфемских промена при њиховом спајању у процесима обличког и творбеног грађења, посебно

${ }^{2}$ У последње две наведене књиге укључени су и неки професорови раније публиковани радови чије ћемо библиографске податке, приликом њиховог набрајања и представљања, навести према месту и времену првог публиковања, док ће се цитати из тих радова тј. њихове библиографске референце наводити према књигама у којима су сабрани.

${ }^{3}$ „По свом постанку консонантске алтернације су резултат фонетских закона од којих су неки и сада присутни и актуелни у нашем језику (једначење по звучности или по месту творбе), а други припадају језичкој историји и сачувани су заправо само њихови резултати у виду алтернација. Алтернације које су резултат поменутих једначења врше се увек, или скоро увек, кад се за њих стекну фонетски услови [...] и могле би се назвати фонетским варијантама, за разлику од ових других које имају историјски резултативни карактер и често су подложне неутрализацији иако за њих постоје фонетски услови [...], а са друге стране јављају се и тамо где за њих нема, нити је икада било, фонетских услова" (Стакић 2002: 166).

${ }^{4}$ „Однос основе и суфикса у погледу алтернација може бити различит: да суфикс утиче на промену завршетка основе (рук-ица $\rightarrow$ руч-ица), да основа утиче на мењање облика суфикса (ткач-ски $\rightarrow$ ткач-ки), да је утицај обостран (праг-ьски $\rightarrow$ праж-ьски $\rightarrow$ прашски $\rightarrow$ прашки)" (Стакић 2002: 173). 
оним из области деривационе фонетике тј. гласовних алтернација на споју творбених морфема (Улога перинтеграиије у јужнословенској именској деривацији, Научни састанак слависта у Вукове дане, 16/1, Београд, 1986, 177-183; Консонантске алтернаиије код именица и придева изведених суфиксима са сугласником Jу јужнословенским језицима, Анали Филолошког факултета, XVI, Београд, 1984, 67-92; Дериваиионо-фонетске особине суфикса -ина и његових деривата у јужнословенским језищима, Радови LXXXIV, књ. 23, АНУБиХ, Сарајево, 1989, 97-112; Консонантске алтерначије изведених именица и придева у јужнословенским језииима, Анали Филолошког факултета, XIX, Београд, 1992, 157-175; Деривачиони морфонолошки дублети у српском језику, Српски језик, 1-2, Београд, 1996, 149-162; Видови дериваџионе основе именских речи у српском језику, Књижевност и језик, 4, Београд, 1997, 11-16; Дериваџиона фонетика-у ужем смислу, Српски језик, 1-2, Београд, 1998, 109-124; Врсте речи и структура деривачионе основе именица и придева у српском језику, Научни састанак слависта у Вукове дане, Београд, 1998, 273-278; Семантичко диферениирање деривачиних дублета, Морфонологија и деривација, Београд, 2002, 239-248). Разматрање морфонолошких алтернација у наведеним радовима увек је прецизно постављено (у смислу разграничења морфонолошких појава од фонолошких), с јасном представом о томе да ове алтернације, иако имају фонетску природу (и са генетске и са синхронијске тачке гледишта), не могу бити објашњене на основу чисто фонолошких података и да су диктиране и условљене правилима граматике, а не фонологије. У том смислу ови радови представљају узорне огледе начина на који морфонолошка тематика треба да буде третирана.

Посебну пажњу у овом домену професор је посветио проблему односа гласовних промена и гласовних алтернација као појавама фонетског односно морфонолошког реда, односу гласовних промена и аналогије односно фонетских и аналошки мотивисаних алтернација, разлици између дијахронијског и синхронијског схватања појма гласовног закона, те питању тзв. изузетака (упор. поред већ наведених и следеће радове: Дијахрони и синхрони аспекти гласовних закона, Српски језик, VII/1-2, Београд, 2002, 251-262; Морфонолошке појаве у граматичком систему Михаила Стевановића, Зборник радова са научног скупа „Живот и дјело академика Михаила Стевановића”, Црногорска академија наука и умјетности, Подгорица, 2002, 219-225; Гласовни процеси и аналошка уопштавања, Зборник радова са научног скупа „Пети лингвистички скуп Бошковићеви дани”, Црногорска академија наука и умјетности, Подгорица, 2003, 281-287; Морфонолошка правила и изузеци, Научни састанак слависта у Вукове дане, 35/3, Београд, 2007, 45-57. и др.).

Важност прецизирања теоријског оквира и методолошког приступа у тумачењу датих појава, као и њихових терминолошких одређења, наглашено је истакнута у чланцима посвећеним анализи ставова других лингвиста који 
су се овом тематиком бавили и који су дати у савременим уџбеницима и приручницима намењеним универзитетској настави српског језика, као и у граматичким уџбеницима за основну и средњу школу (в. одељак 2.6).

У наставку овог рада ми ћемо се нешто опширније осврнути на ове теме, кључне за професорово бављење проблемима морфонологије и деривације, у настојању да осветлимо суштину његових теоријских ставова.

2.1. Аксиом о неповредивости фонетских закона био је формулисан још седамдесетих година 19. века од стране младограматичара. Од тог времена крећу и спорења о научној оправданости ове тезе због једног парадокса који су још младограматичари уочили, а то је да принципска тврдња о неповредивости фонетских закона бива нарушена постојањем изузетака. Покушај да се ослободе овог, показало се теоријски веома плодног парадокса, водила је младограматичаре до модификације става о неповредивости фонетских закона и настојања да се њихово нарушавање објасни променом неког од параметара којима је фонетски закон условљен. ${ }^{5}$ У доцнијим критикама младограматичарске теорије централно место је заузела ревизија њихових схватања о природи фонетских закона, њиховој регуларности, односно изузецима, те се утврдило да привидни изузеци могу бити резултат деловања другог закона (који је опозвао дејство првог), позајмљивања из другог језика или дијалекта и нефонетских промена гласовне структуре речи. За ову последњу промену младограматичари су истакли принцип морфолошке аналогије као закономерног извора изузетака. Тиме је почетни младограматичарски постулат прецизиран и постао теоријско-методолошки драгоцен.

Професор Стакић је у своје разматрање односа гласовних промена и гласовних алтернација увео теоријски и методолошки веома продуктиван критеријум хронологизације разматраних језичких појава, односно различитих етапа у којима фонетске промене настају, развијају се и преображавају. Прву етапу чине гласовне промене синхронијског функционисања тј. оне које се дешавају у строго одређеним фонетским позицијама, у датом језику (дијалекту), на одређеној хронолошкој етапи његовог развитка. Друга наступа тек после губљења позиционе условљености и фонологизације првобитних алофона, те се нова фонема може морфологизовати тј. везати за одређене морфолошке позиције и функционисати као обележје одређене обличке или творбене дистинкције: „У морфонологији треба увек имати у виду две кључне чињенице: прво - да су гласовне промене и гласовне алтернащије различити појмови и хронолошки и семантички и функционално, и друго - да се у савременом језику може и мора говорити само о гласовним алтернацијама. Гласовне промене су предмет историје језика, настајале су деловањем гласовних закона који су били

${ }^{5}$ Према младограматичарској теорији, гласовне промене се дешавају у строго одређеним фонетским позицијама, у датом језику, на одређеној историјској етапи његовог развитка. 
актуелни, углавном, у прошлости, најчешће у врло давној прошлости, и увек у фонетском окружењу, без значења и функције. А кад се процес гласовних промена заврши, кад гласовни закони ослабе или сасвим престану да делују, њихови резултати се користе у језичком систему као обележје морфолошких или творбених категорија. Добијају, дакле, уместо фонетског морфолошко окружење, а са њим и семантичност и функционалност, те тако постају гласовне алтернације као део граматичке структуре језика" (Стакић 2010: 29). Ове ставове аутор наглашава и у другим својим радовима: „То смењивање гласова у систему облика једне речи или у грађењу нових речи јесте алтернација а не промена. Та два термина не би се смела поистовећивати ни мешати из више разлога. Промена гласа подразумева нестанак једног и појаву другог уместо њега, не могу истовремено егзистирати оба (нема фонетских дублета!), и то се дешава у фонетском окружењу без икаквих изузетака и једнако у корену, суфиксу, префиксу, наставку за облик - свугде где се створе фонетски услови. Друго, промена гласа увек подразумева временску дистанцу од основног, почетног до измењеног, завршног облика, временску сукцесију (зато су гласовне промене искључиво дијахроне појаве!) и самим тим нема им места у опису савременог стања језика. И треће, најважније, нису све алтернације производ гласовних промена, многе су настале аналогијом” (Стакић 2010: 14).

2.2. Аналогији, као једном од основних принципа језичког стварања које делује по неком постојећем моделу, проф. Стакић посвећује доста пажње, разматрајући овај процес у опозицији према гласовним променама, утврђујући њену улогу у неким алтернацијама које нису фонетски условљене и њено место у разматрању питања изузетака. Професорова промишљања о аналогији полазе од младограматичарских ставова о једном „психолошким” механизмима мотивисаном процесу, али своје зрење дугују његовој структуралистичкој литератури и њеном теоријском конструкту. У раду Гласовни процеси и аналошка уопштавања он вели да „у целости граматичка и синхронијска”, аналогија је „и психолошке и граматичке природе, а то значи, да за разлику од фонолошке промене која је лишена значења, аналогија подразумева свест, идеју и разумевање односа који уједињују облике међусобно" (Стакић 2010: 15). Објашњавајући дејство аналогије на бројним примерима старословенског и српског језика, професор утврђује да гласовне промене и аналогија „делују у истој равни", само што прве претходе другој и истиче две битне разлике међу њима: „1) фонетске промене су дијахронијски појам, предмет историје језика, а аналогија је синхронијска појава, везана за говор и језичко осећање говорника, 2) фонетска промена, фонолошки условљена фонетска промена је лишена значења, није граматичка (може се пратити мењање гласова једне речи не улазећи у њено значење), док је аналогија граматичка појава везана за значење и облике појединих речи. То им, међутим, не смета да делују у истом правцу и међусобно се допуњују” (Стакић 2010: 21-22). 
При разматрању односа фонетски и морфолошки условљених алтернација у различитим деривационим типовима, професор Стакић увек има у виду и семантички моменат тј. могућност морфолошког, прецизније - аналошког уопштавања деривационих основа према семантички сродним творбеним типовима у којима су постојали фонетски услови за дату алтернацију (нпр.: ручурда, ножурда према ручетина, ножетина; језичав, пупчат са основом уопштеном према семантички сродним творбеним типовима са суфиксом -ив; Бошњак, сељак према именицама исте семантичке категорије на суфикс -јанин: Бошььнин, сељанин, итд.): „На крају и уопштено - све наведене и објашњаване врсте консонантских алтернација на морфемском шаву могли бисмо поделити у две групе: оне које су резултат деловања фонетских промена и оне друге, које се углавном срећу у деривацији, а не могу се у датом деривационом односу и у датој творбеној анализи објаснити фонетски, које су, другим речима, морфолошке или деривационе, у крајњој анализи, аналошке природе. За оне прве, гласовног порекла, најважнија је фонолошка структура морфема, а за ове друге, аналошке, пресудна је семантичка страна изведене речи, њено ослањање на сродне и продуктивне творбене типове исте семантичке категорије" (Стакић 2002: 172).

2.3. О свим овим типовима алтернација, о њиховом пореклу и суштини, професор Стакић је најпре писао у својој дисертацији Деривациона фонетика именица и придева у јужнословенским језицима (Београд, 1988, стр. 1-244). Алтернације он ту разврстава према творбеним типовима, односно именичким и придевским суфиксима који се у њима јављају, с циљем да се да преглед деривационих алтернаната свих консонаната (и оних праиндоевропских по пореклу и прасловенских) и да тај преглед обухвати све јужнословенске језике. У својој дисертацији он је покренуо и многа питања везана за теорију творбе речи: семантичке категорије и творбени типови изведеница, постанак суфикса и њихово везивање за различите основе, унутрашње богаћење значења изведеница, перинтеграција и њена улога у настанку бројних суфиксних деривата, историјско губљење алтернација, дублети и друга сродна питања.

Проучавању питања из области творбе речи и морфонологије као узајамно повезаним и неодвојивим дисциплинама професор Стакић остаје посвећен и доцније, те су у многим његовим радовима ова питања била даље развијана и прецизирана. Поред већ спомињаних, на пример и у радовима Деривациони морфонолошки дублети у српском језику и Семантичко диференцирање деривациних дублета, посвећеним дублетима, њиховом постанку, развитку и њиховој судбини у српском језику, где се кроз бројне примере творбених типова именица и придева анализира сам деривациони однос, структура суфикса, врсте алтернације, те семантичке промене које могу довести до њихове диференцијације (упор. Стакић 2002: 215-237, 239-248). 
2.4. Питање изузетака било је, како смо већ споменули, онај плодан парадокс чије је теоријско осмишљавање довело до првобитно неслућених и за словенску и индоевропску компаративистику значајних консеквенци. Дотичући се не једанпут овог проблема (упор. нпр. радове: Дијахрони и синхрони аспекти гласовних закона, Гласовни процеси и аналошка уопштавања, Морфонолошке појаве у граматичком систему Михаила Стевановића), професор Стакић утврђује да гласовне промене и фонетски закони који их описују бивају актуелни на нивоу свог синхронијског функционисања и тада позиционо варирање фонема нема изузетака, али их нема ни на етапи морфологизације резултата фонетских промена: „Не може их бити док се врши гласовна промена, она је под истим условима обавезна, свеобухватна. А кад се алтернације вежу за морфолошке и творбене облике, семантички моменат је пресудан - кад се угрози значење речи или њеног облика, алтернација ће изостати, јер она није ни обавезна ни свеобухватна. Ни ту, дакле, нема изузетака јер они подразумевају постојање правила, а правило је: ако се облик речи удаљи од основног (или изведена реч од мотивне), чиме би се замаглило или угрозило значење - алтернација ће изостати. О одступањима/изузецима ће се говорити (и често се говори) само ако се помешају синхронија и дијахронија, ако се у савременом језику говори о гласовним променама, које су се вршиле и извршиле у даљој или ближој прошлости. А сме ли се то чинити?” (Стакић 2010: 50-51). Овај подужи цитат навели смо с разлогом, јер се на проблему изузетака преламају сви значајни професорови теоријски ставови о односу гласовних промена и гласовних алтернација, историјских и актуелних језичких законитости, методолошким правилима о немешању синхронијског и дијахронијског проучавања језичких појава.

2.5. Сва ова питања из области морфонологије и деривације, на која смо се у претходним пасусима осврнули, срећемо и у радовима професора Стакића посвећеним њиховом тумачењу у делима неких других лингвиста и уџбеницима и граматикама српског језика. Ту су свој фокус и одраз нашле и све претходно наведене професорове теме, и његов методички дар и интересовање за наставу српског језика, и његова увек млада склоност да свако, наизглед у науци решено питање, у дијалогу са онима који су о њему већ говорили, преиспитује и разматра са различитих аспеката (упор. нпр. Палатализачије и алтерначије задњонепчаних сугласника, Српски језик, V/1-2, Београд, 2000, 339-356; Морфонолошке гласовне алтернащије у настави српског језика, Књижевност и језик, 3-4, Београд, 2001, 63-76; Морфонолошке појаве у граматичком систему Михаила Стевановића, Зборник радова са научног скупа „Живот и дјело академика Михаила Стевановића”, Црногорска академија наука и умјетности, Подгорица, 2002, 219-225; Морфонолошка терминоло-

${ }^{6}$ В. Стакић 2010: 7-28; 
гија у настави српског језика, Научни састанак слависта у Вукове дане, 34/3, Београд, 2005, 169-175; Морфонолошка правила и изузещи, Научни састанак слависта у Вукове дане, 35/3, Београд, 2007, 45-57. и др.).

Мотив за писање радова са овом темом професор Стакић налази у умногоме разноликом тумачењу ових питања у факултетским и школским граматикама и приручницима наших савремених лингвиста ${ }^{7}$, као и у великом терминолошком шаренилу и неодређености која у овој области влада. Порекло ове „смутње” професор види у утицају традиције и историзма којима ни савремени уџбеници нису одолели (Стакић 2010: 38) и који се повлачи још од наших првих граматичара нормативиста, односно у методолошки недопустивом мешању синхронијског и дијахронијског аспекта при анализи: „методски је погрешно, а научно неодрживо да се у опису савременог стања језика говори о гласовним променама. Има смисла говорити само о њиховим резултатима у флексији и деривацији, говорити, дакле, о алтернацијама, које не морају увек бити гласовног порекла, продукт фонетских закона, каткад су оне морфолошког порекла, резултат аналошког уопштавања. Све гласовне промене требало би изучавати у историји језика јер оне подразумевају временску дистанцу у процесу мењања једног гласа у други. Тако добијен 'сирови материјал' језик користи у граматичке сврхе, дајући му семантичко обележје. [...] О изузецима (или боље „изузецима”) излишно је говорити јер они не постоје. Оно што се под њима подразумева јесу новије појаве у језику и личе на изузетке само кад се направи погрешан спој синхроније и дијахроније. У дијахронији, у гласовним законима они не постоје јер се гласовне промене врше без изузетака, а у синхронији кад се говори о алтернацијама, опет нема места изузецима јер сихронијски закони немају императивност." (Стакић 2010: 15-16).

Радови овог типа, у којима се преиспитују неки актуелни теоријски ставови и методолошки приступи у којима се они одражавају, ретки су и вредни не само за оне који се баве писањем уџбеника или њиховим оцењивањем, већ и за бројне наставнике који их у својој пракси могу користити као драгоцену и поуздану литературу. У њима се огледа и она лепа особина која је лингвисту Милана Стакића увек красила и издвајала - он никада није запостављао професонални део свог научног битка, увек је био и професор који поучава.

${ }^{7}$ У радовима се анализира терминологија, тумачење и дефинисање појма гласовних закона, њихових изузетака (одступања), односа гласовних промена и алтернација (као различитих фонолошких, односно морфонолошких појава), фонетски и морфолошки (аналошки) мотивисаних алтернација итд. - у универзитетском уџбенику Савремени српскохрватски језик 1 Михаила Стевановића, Енциклопедијском лексикону Мозаик знања (1: Српскохрватски језик), те у трима актуелним средњошколским и основношколским уџбеницима - Граматици српског језика Живојина Станојчића и Љубомира Поповића, Језику и језичкој култури Љ. Николић, Ж. Станојчића и Д. Кликовац, Граматици српског језика за основну школу Д. Кликовац, као и у Српској граматици Р. Симића. 
3. Од почетака научне каријере професора Милана Стакића морфонологија и деривација су постојано заокупљале његову пажњу и биле повезане као две узајамно прожимајуће и комплементарне области. Њима се он кретао теоријски суверено и методолошки лако, у плодном сустицању својих различитих научних позвања, са смислом и за она танана питања која ове дисциплине размеђавају и за она кључна која их спајају. Сваком ко се овим областима буде бавио остаће његови радови и као поуздане основе од којих могу започети будућа трагања и као пример како се језиком једноставним и стилом прочишћеним од сваког замагљивања, апстракције и двосмислености неке лингвистичке теме могу преиспитивати од оног извора од којег су потекле, преко спорих меандара научног преиспитивања или оспоравања, до свог документованог и веродостојног разрешења.

\section{ЛИТЕРАТУРА}

Стакић 1988: М. Стакић, Деривациона фонетика именица и придева у јужнословенским језицима, Београд: Филолошки факултет, 244 стр.

Стакић 2002: М. Стакић, Морфонологија и дериващија (чланщи и расправе), Београд: Филолошки факултет, Научно друштво за неговање и проучавање српског језика, 317 стр.

Стакић 2010: М. Стакић, Морфо(но)лошке теме, Београд: Друштво за српски језик и књижевност Србије, 201 стр. 


\title{
MORPHONOLOGY IN PROFESSOR MILAN STAKIĆ'S ACADEMIC WORK
}

\begin{abstract}
Summary
An analysis of the theoretical views and methodological approaches presented by Professor Milan Stakić in his papers and studies in the field of morphonology has demonstrated that his conceptions of key issues and matters linking this linguistic discipline with the areas of phonology and morphology on the one hand and with the complementary area of derivation on the other hand - was founded on their location as synchronic-diachronic linguistic phenomena. As far as the considerations of these different aspects during his interpretations is concerned, Professor Stakić clearly divided them in theory and accurately executed in methodology, ranging from the initial tenets of the Neogrammarians and their subsequent revision, via the structuralist understanding of these phenomena, to his own reconsiderations and a critique of their interpretation in contemporary Serbian linguistics.

Keywords: morphonology, sound changes, sound alternations, analogy, exceptions, Milan Stakić, theory, methodology.
\end{abstract}

